\title{
THE LOGGERHEAD TURTLES IN JAPAN AND NEIGHBORING WATERS (TESTUDINATA : CHELONIIDAE)
}

AUTHOR(S):

Nishimura, Saburo

\section{CITATION:}

Nishimura, Saburo. THE LOGGERHEAD TURTLES IN JAPAN AND NEIGHBORING WATERS (TESTUDINATA : CHELONIIDAE). PUBLICATIONS OF THE SETO MARINE BIOLOGICAL LABORATORY 1967, 15(1): 19-35

ISSUE DATE:

1967-05-25

URL:

http://hdl.handle.net/2433/175456

RIGHT: 


\title{
THE LOGGERHEAD TURTLES IN JAPAN AND NEIGHBORING WATERS (TESTUDINATA : CHELONIIDAE) ${ }^{1)}$
}

\author{
SABURO NISHIMURA \\ Seto Marine Biological Laboratory, Sirahama
}

With 5 Text-figures

There have been some confusions in the taxonomy and nomenclature of the loggerhead turtles occurring in the Japanese and adjacent waters. Most of previous authors regarded the population of the turtles found or caught in Japan and her adjoining waters as consisting of a single species, and applied to it the name Caretta olivacea (Eschscholtz) or Caretta caretta olivacea (Eschscholtz) (Stejneger 1907; Taylor 1921; Okada 1927, 1938, 1947; Takashima 1932; Pope 1935; Hrrasaka 1943; Utinomi 1943; Nakamura 1957; Нотta 1960; etc.) These authors were, however, not right in two points: first they were not aware of the existence of two distinct species in the populations of the Japanese loggerhead species, and secondly some of them failed to find the correct scientific name for the commoner one generally known by the Japanese name 'aka-umigame' (aka means red, umigame means sea turtle). For the first time in 1963, NAKAmURA and UÉNo revealed that the loggerhead turtles caught in the Japanese waters consist really of two distinct species belonging to the two different genera and designated them respectively as Caretta caretta gigas DeraniyaGALA and Lepidochelys olivacea olivacea (Eschscholtz). Though the distinction and the descriptions of the two species by these authors were made properly, for some unknown reason the two scientific names were assigned to erroneously; i.e., Lepidochelys olivacea olivacea was applied to the true Caretta caretta (red-brown loggerhead in English; aka-umigame in Japanese) and Caretta caretta gigas was applied to the real Lepidochelys olivacea (Pacific ridley or olive loggerhead in English; hime-umigame in Japanese) (cf. Nishimura \& HaRA 1967).

Meanwhile, almost nothing has been described on the morphological details of the red-brown loggerhead population in Japan, though this sea turtle is quite common there as will be shown later (presumably this country may be the place of the densest occurrence throughout the western Pacific areas). This has made it difficult to scrutinize the opinion held by some herpetologists that the red-brown loggerhead is separable into the Indo-Pacific subspecies and its Atlantic counterpart (DeraniYagala 1933, 1939, 1943, 1945, 1946; Carr 1952; Wermuth \& Mertens 1961; etc.)

1) Contributions from the Seto Marine Biological Laboratory, No. 465.

Publ. Seto Mar. Biol. Lab., XV (1), 19-35, 1967. (Article 3) 
The present paper is prepared as the first step in the studies to reveal the details of the morphological characters of the loggerhead population breeding in southern Japan for the purpose of firstly showing definitely that the population is represented by a single species caretta Linné, not olivacea Eschscholtz, and secondly presenting a datum for future discussions on the subspecies problem of Caretta caretta on a world-wide scale.

Before going further, I wish to extend my hearty thanks to many persons who helped me in various ways; particularly I am indebted to Mr. Y. Shibata of the Osaka Museum of Natural History for his generosity in allowing me to avail his herpetological literature, and to Mr. Ch. Sugrhara of Sakata City, Yamagata Prefecture, for his kind information of the records of sea turtles in that province. The paper was read by Prof. H. Utinomi and Dr. T. TокіокA of our laboratory, to whom I am so grateful.

\section{Loggerhead Turtles from Sirahama and Other Localities in Southern Japan}

In June to early August, at some nights of calm wind and bright moon light, some loggerheads will land on the sandy beach near the Seto Marine Biological Laboratory for egg laying. After the incubation of about two months, baby turtles hatch out. And usually one or two clutches of these newly-hatched baby turtles are brought to the laboratory aquarium where they are reared, being fed with fish meat; and occasionally some of them live more than ten years under human care. Thus, in September 1966, about a hundred hatchlings, four one-year individuals, five twoyear individuals and several larger individuals of different ages are kept alive in the aquarium. In addition, some stuffed specimens are displayed in the specimen gallery of the aquarium. They are all from the vicinity of the laboratory, some in recent years and others long ago. These specimens, living and stuffed, form the material for the discussion made in this section.

Results of the measurement on the carapace of all the specimens examined are given in Table 1, and figures of the carapace, inframarginal scutes, head shields and mandibular scales of some representative specimens are presented in Figs. 1 to 4. The features shown in the table and text-figures, together with the characteristic red-brown coloration of the carapace, which becomes clear in the individuals older than one year or larger than about $15 \mathrm{~cm}$ in carapace length, are sufficient enough to assign all of the examined specimens to a single species Caretta caretta (LinNé, $1758)^{2)}$.

In describing and discussing the characters of these specimens, those of the olive loggerhead Lepidochelys olivacea (Eschscholtz, 1829) will be referred to frequently for

2) Subspecific separation suggested by Deranryagala (1933, etc.) and some other authors is not followed here, for the validity of subspecies does not seem wholly established. 
comparison, since these two loggerheads have been confused so much in Japan and are still so in certain districts in the western Pacific.

Shape of Carapace. As seen in Table 1, the width varies from 74.2 to $94.4 \%$ of the length in the Sirahama specimens with 40 to $930 \mathrm{~mm}$ long carapace. These values nearly coincide with those given by Brongersma (1961) for the Atlantic specimens of Caretta caretta. Besides the individual variation of a considerable wide range, there is seemingly a trend towards the decrease in relative width of the carapace with the growth. In Lepidochelys olivacea of similar size, on the other hand, the carapace is a little wider: CADENAT (1949) cites the carapace of three specimens of this species, 525
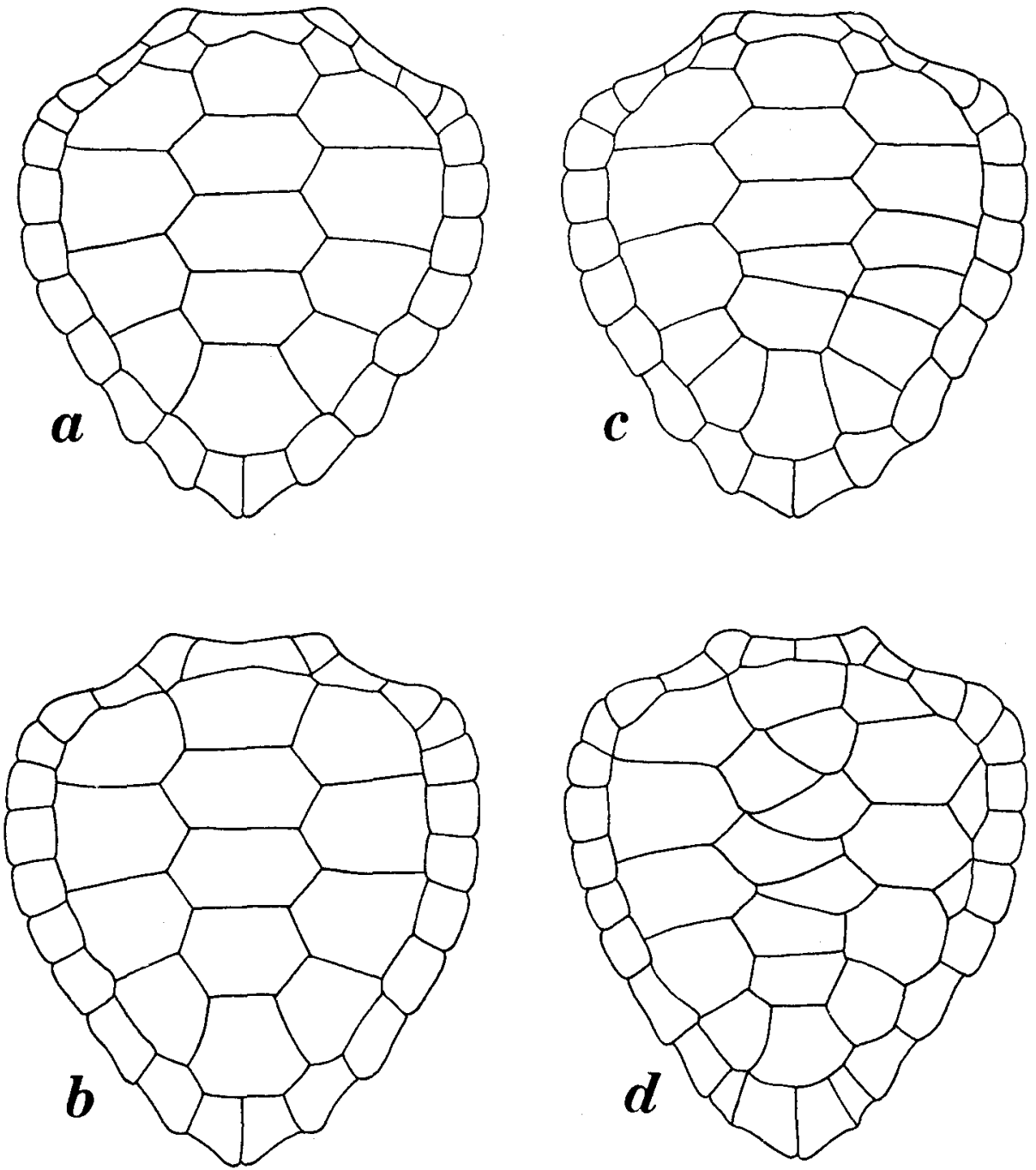

Fig. 1. Variations in the pattern of carapace scutes in hatchlings of Caretta caretta (LiNNÉ) from Sirahama.

a.-Specimen no. 6627 ; b.-Specimen no. 6633 ; c.-Specimen no. 6628 ; d.-Specimen no. 6630. 
Table 1. Measurements on Caretta caretta (LinNé) from Sirahama, southern Japan. Specimen nos. 6601 to 6625,6626 to $6633,6634 \& 6635,6636$ to 6640,6641 to 6660,6501 to 6504 and 6401 to 6405 are respectively from the same clutch. Nos. OB1 to OB9 are each from different clutches.

\begin{tabular}{|c|c|c|c|c|c|c|c|c|c|c|c|}
\hline \multirow{2}{*}{$\begin{array}{l}\text { Speci- } \\
\text { men } \\
\text { no. }\end{array}$} & \multicolumn{3}{|c|}{ Carapace } & \multirow[b]{2}{*}{ Vert. } & \multicolumn{2}{|c|}{ Costals } & \multicolumn{2}{|c|}{ Marginals* } & \multicolumn{2}{|c|}{ Inframarginals** } & \multirow{2}{*}{$\begin{array}{c}\text { Infra- } \\
\text { marginal } \\
\text { pore }\end{array}$} \\
\hline & Length & Width & $\begin{array}{c}100 \times \\
\mathrm{W} / \mathrm{L}\end{array}$ & & $l$ & $r$ & $l$ & $r$ & $l$ & $r$ & \\
\hline 6601 & $40 \mathrm{~mm}$ & $34 \mathrm{~mm}$ & 85.0 & 5 & 5 & 5 & (1) 12 & (1) 12 & (1) 3 & (1) 3 & None \\
\hline 6602 & & 35 & $\begin{array}{l}0.0 \\
87.5\end{array}$ & 5 & 5 & 5 & (1) 12 & 12 & 4 & (1) 3 & None \\
\hline 6603 & 41 & & 82.9 & 5 & 5 & 5 & 12 & 12 & (1) 3 & 4 & None \\
\hline 6604 & 41 & 34 & 82.9 & 5 & 5 & 5 & 12 & 12 & 3 & (1) 3 & None \\
\hline 6605 & 41 & 34 & 82.9 & 5 & 5 & 5 & 12 & 12 & (1) 3 & (1) 3 & None \\
\hline 6606 & 41 & 35 & 85.3 & 5 & 5 & 5 & (1) 12 & (I) 12 & 4 & (1) 3 & None \\
\hline 6607 & 41 & 35 & 85.3 & 5 & 5 & 5 & 12 & (1) 12 & (1) 3 & (i) 3 & None \\
\hline 6608 & 41 & 35 & 85.3 & 5 & 5 & 5 & (1) 12 & (1) 12 & 4 & 4 & None \\
\hline 6609 & 41 & 35 & 85.3 & 5 & 5 & 5 & 13 & (3) 11 & (1) 3 & (1) 3 & None \\
\hline 6610 & 41 & 35 & 85.3 & 5 & 5 & 5 & (1) 12 & (1) 12 & 4 & (1) 3 & None \\
\hline 6611 & 41 & 36 & 87.8 & 5 & 5 & 5 & 12 & 12 & (1) 3 & (1) 3 & None \\
\hline 6612 & 42 & 32 & 76.3 & 5 & 5 & 5 & (1) 12 & 12 & (1) 3 & 4 & None \\
\hline 6613 & 42 & 35 & 83.3 & 5 & 5 & 5 & 12 & 12 & (1) 3 & (1) 3 & None \\
\hline 6614 & 42 & 35 & 83.3 & 5 & 5 & 5 & (1) 12 & 12 & (1) 3 & (1) 3 & None \\
\hline 6615 & 42 & 35 & 83.3 & 5 & 5 & 5 & (1) 12 & 12 & 4 & 4 & None \\
\hline 6616 & 42 & 36 & 85.8 & 5 & 5 & 5 & 12 & (1) 12 & (I) 3 & (1) 3 & None \\
\hline 6617 & 42 & 36 & 85.8 & 5 & 5 & 5 & 13 & 13 & (1) 3 & (1) 3 & None \\
\hline 6618 & 42 & 36 & 85.8 & 5 & 5 & 5 & 12 & 12 & (1) 3 & (1) 3 & None \\
\hline 6619 & 42 & 35 & 83.3 & 5 & 5 & 5 & (1) 12 & 12 & (1) 3 & (1) 3 & None \\
\hline 6620 & 42 & 35 & 83.3 & 5 & 5 & 5 & (1) 12 & 12 & 4 & 4 & None \\
\hline 6621 & 42 & 36 & 85.8 & 5 & 5 & 5 & 12 & 12 & (1) 3 & (1) 3 & None \\
\hline 6622 & 42 & 36 & 85.8 & 5 & 5 & 5 & (1) 12 & (1) 12 & 4 & (1) 3 & None \\
\hline 6623 & 42 & 36 & 85.8 & 5 & 5 & 5 & 12 & 12 & (1) 3 & (1) 3 & None \\
\hline 6624 & 42 & 36 & 85.8 & 5 & 5 & 5 & (1) 12 & (1) 12 & (1) 3 & 4 & None \\
\hline 6625 & 43 & 35 & 81.4 & 5 & 5 & 5 & 12 & (1) 12 & (1) 3 & 4 & None \\
\hline 6626 & 42 & 39 & 92.8 & 5 & 5 & 5 & (3) 11 & 12 & 4 & (1) 3 & None \\
\hline 6627 & 43 & 39 & 90.7 & 5 & 5 & 5 & 12 & 12 & 4 & 4 & None \\
\hline 6628 & 43 & 40 & 93.1 & 6 & 6 & 7 & 12 & 12 & 4 & (1) 3 & None \\
\hline 6629 & 43 & 40 & 93.1 & 5 & 6 & 5 & $(2) 11$ & (2) 11 & (1) 3 & (1) 3 & None \\
\hline 6630 & 44 & 39 & 88.7 & 9 & 5 & $5(\mathrm{SC} 2)+$ & $11(1) 1$ & $11(1) 1$ & 4 & 4 & None \\
\hline 6631 & 44 & 40 & 90.9 & 5 & 5 & 5 & 12 & 12 & (1) 3 & (1) 3 & None \\
\hline 6632 & 44 & 40 & 90.9 & 5 & $4(\mathrm{SC} 1)$ & $4(\mathrm{SC} 2)$ & 12 & 12 & (1) 3.5 & (1) $3(1)$ & None \\
\hline 6633 & 46 & 40 & 87.0 & 5 & 4 & 4 & 12 & 12 & 3 & 3 & None \\
\hline 6634 & 44 & 38 & 86.4 & 5 & 5 & 5 & $1(1) 11$ & $1(1) 11$ & 4 & 4 & None \\
\hline 6635 & 51 & 47 & 92.2 & 5 & 5 & 5 & (2) 11 & 12 & 4 & (1) 3 & None \\
\hline 6636 & 45 & 38 & 84.4 & 5 & 5 & 5 & $1(1) 11$ & $1(1) 11$ & 4 & 4 & None \\
\hline 6637 & 45 & 38 & 84.4 & 5 & 5 & 5 & 12 & 12 & 3 & 3 & None \\
\hline 6638 & 45 & 39 & 86.7 & 5 & 5 & 5 & $1(1) 11$ & $1(1) 11$ & (1) 3 & 4 & None \\
\hline 6639 & 45 & 40 & 88.9 & 5 & 5 & 5 & (2) 11 & $1(1) 11$ & (1) $3(1)$ & (1) 4 & None \\
\hline 6640 & 46 & 40 & 86.9 & 5 & 5 & 5 & (2) 11 & $1(1) 11$ & (1) 3 & (1) 3 & None \\
\hline 6641 & 49 & 44 & 89.8 & 5 & 5 & 5 & (2) 11 & (2) 11 & 4 & (1) 3 & None \\
\hline 6642 & 49 & 44 & 89.8 & 5 & 5 & 5 & (2) 11 & (2) 11 & 4 & 4 & None \\
\hline 6643 & 49 & 45 & 91.8 & 5 & 5 & 5 & 12 & 12 & (1) $3(1)$ & 3 & None \\
\hline 6644 & 50 & 45 & 90.0 & 5 & 5 & 5 & 12 & 12 & (1) 4 & (1) 3 & None \\
\hline 6645 & 50 & 46 & 92.0 & 5 & 5 & 5 & $1(1) 11$ & $1(1) 11$ & 5 & (1) 4 & None \\
\hline 6646 & 50 & 46 & 92.0 & 5 & 5 & 5 & 12 & 12 & (1) 3 & (1) $3(1)$ & None \\
\hline 6647 & 50 & 47 & 94.0 & 5 & 5 & 5 & 12 & 12 & 4 & $(1) 4$ & None \\
\hline 6648 & 51 & 46 & 90.3 & 5 & 5 & 5 & $11(1) 1$ & 12 & $3.5(1)$ & $4(1)$ & None \\
\hline 6649 & 51 & 47 & 92.2 & $4(1) 1$ & 6(SC1) & 6(SC1) & 12 & $1\langle 1\rangle 11$ & (1) $4^{\prime \prime}$ & 4 & None \\
\hline 6650 & 52 & 49 & 94.3 & 5 & 5 & 5 & 12 & 12 & (1) 4 & (1) 4 & None \\
\hline 6651 & 53 & 47 & 88.7 & 5 & 5 & 5 & 12 & 12 & (1) 3 & (1) 3 & None \\
\hline 6652 & 53 & 48 & 90.6 & 5 & 5 & 5 & 12 & 12 & (1) 4 & (1) 4 & None \\
\hline 6653 & 53 & 49 & 92.5 & 5 & 5 & 5 & 12 & 12 & 4 & (1) 3 & None \\
\hline 6654 & 53 & 50 & 94.4 & 5 & 5 & 5 & 12 & 12 & (1) 3 & (1) 3 & None \\
\hline
\end{tabular}


Table 1 (continued).

\begin{tabular}{|c|c|c|c|c|c|c|c|c|c|c|c|}
\hline \multirow{2}{*}{$\begin{array}{c}\text { Speci- } \\
\text { men } \\
\text { no. }\end{array}$} & \multicolumn{3}{|c|}{ Carapace } & \multirow{2}{*}{ Vert. } & \multicolumn{2}{|c|}{ Costals } & \multicolumn{2}{|c|}{ Marginals* } & \multicolumn{2}{|c|}{ Inframarginals $* *$} & \multirow{2}{*}{$\begin{array}{c}\text { Infra- } \\
\text { marginal } \\
\text { pore }\end{array}$} \\
\hline & Length & Width & $\frac{100 \times}{W / L}$ & & $l$ & $r$ & $l$ & $r$ & $l$ & $r$ & \\
\hline $\begin{array}{l}6655 \\
6656 \\
6657 \\
6658 \\
6659 \\
6660\end{array}$ & $\begin{array}{l}54 \mathrm{~mm} \\
54 \\
54 \\
54 \\
55 \\
55\end{array}$ & $\begin{array}{l}48 \mathrm{~mm} \\
49 \\
50 \\
50 \\
49 \\
51\end{array}$ & $\begin{array}{l}88.9 \\
90.8 \\
92.6 \\
92.6 \\
89.2 \\
92.8\end{array}$ & $\begin{array}{l}5 \\
5 \\
5 \\
5 \\
5 \\
5\end{array}$ & $\begin{array}{l}5 \\
5 \\
5 \\
5 \\
5 \\
5\end{array}$ & $\begin{array}{l}5 \\
5 \\
5 \\
5 \\
6 \\
5\end{array}$ & $\begin{array}{c}\text { (1) } 12 \\
12 \\
12 \\
1(1) 11 \\
12 \\
12\end{array}$ & $\begin{array}{c}\text { (1) } 12 \\
12 \\
12 \\
1(1) 11 \\
12 \\
12\end{array}$ & $\begin{array}{l}\text { (1) } 3 \\
4 \\
(1) 3 \\
(1) 3 \\
(1) 3 \\
\text { (1) } 3\end{array}$ & $\begin{array}{c}\text { (1) } 3 \\
4 \\
\text { (1) } 3 \\
\text { (1) } 3 \\
\text { (1) } 3 \\
\text { (1) } 3\end{array}$ & $\begin{array}{l}\text { None } \\
\text { None } \\
\text { None } \\
\text { None } \\
\text { None } \\
\text { None }\end{array}$ \\
\hline $\begin{array}{l}6501 \\
6502 \\
6503 \\
6504\end{array}$ & $\begin{array}{l}118 \\
121 \\
132 \\
139\end{array}$ & $\begin{array}{l}102 \\
109 \\
109 \\
126\end{array}$ & $\begin{array}{l}86.5 \\
90.1 \\
82.7 \\
90.8\end{array}$ & $\begin{array}{c}5 \\
5 \\
4(1) 1 \\
5\end{array}$ & $\begin{array}{l}5 \\
4 \\
5 \\
5\end{array}$ & $\begin{array}{l}5 \\
5 \\
6 \\
4\end{array}$ & $\begin{array}{l}12 \\
12 \\
12 \\
12\end{array}$ & $\begin{array}{l}12 \\
12 \\
12 \\
12\end{array}$ & $\begin{array}{l}\text { (1) } 3 \\
\text { (1) } 3.5 \\
\text { (1) } 3.5 \\
\text { (1) } 3\end{array}$ & $\begin{array}{l}\text { (1) } 3 \\
\text { (1) } 4 \\
\text { (1) } 3 \\
\text { (1) } 4\end{array}$ & $\begin{array}{l}\text { None } \\
\text { None } \\
\text { None } \\
\text { None }\end{array}$ \\
\hline $\begin{array}{l}6401 \\
6402 \\
6403 \\
6404 \\
6405\end{array}$ & $\begin{array}{l}170 \\
175 \\
180 \\
196 \\
210\end{array}$ & $\begin{array}{l}153 \\
155 \\
166 \\
177 \\
188\end{array}$ & $\begin{array}{l}89.9 \\
88.7 \\
92.3 \\
90.3 \\
89.6\end{array}$ & $\begin{array}{l}5 \\
5 \\
5 \\
5 \\
5\end{array}$ & $\begin{array}{c}5 \\
5 \\
5 \\
(1) 4 \\
5\end{array}$ & $\begin{array}{l}5 \\
5 \\
5 \\
4 \\
5\end{array}$ & $\begin{array}{c}12 \\
12 \\
1(1) 11 \\
12 \\
1(1) 11\end{array}$ & $\begin{array}{c}12 \\
12 \\
1(1) 11 \\
12 \\
1(1) 11\end{array}$ & $\begin{array}{c}4 \\
3 \\
(1) 3 \\
(1) 3 \\
\text { (1) } 3\end{array}$ & $\begin{array}{l}\text { (1) } 3 \\
\text { (1) } 4 \\
\text { (1) } 3 \\
\text { (1) } 4 \\
\text { (1) } 3\end{array}$ & $\begin{array}{l}\text { None } \\
\text { None } \\
\text { None } \\
\text { None } \\
\text { None }\end{array}$ \\
\hline $\begin{array}{r}\text { †OB1 } \\
\text { †OB2 } \\
\text { †OB3 } \\
\text { †OB4 } \\
\text { OB5 } \\
\text { †OB6 } \\
\text { OB7 } \\
\text { OB8 } \\
\text { †OB9 }\end{array}$ & $\begin{array}{l}176 \\
185 \\
212 \\
227 \\
415 \\
600 \\
610 \\
920 \\
930\end{array}$ & $\begin{array}{l}162 \\
158 \\
183 \\
205 \\
350 \\
500 \\
485 \\
715 \\
690\end{array}$ & $\begin{array}{l}92.1 \\
85.4 \\
86.3 \\
90.3 \\
84.4 \\
83.3 \\
79.5 \\
77.7 \\
74.2\end{array}$ & $\begin{array}{l}5 \\
5 \\
5 \\
5 \\
5 \\
5 \\
5 \\
6 \\
5\end{array}$ & $\begin{array}{l}5 \\
5 \\
5 \\
5 \\
5 \\
5 \\
5 \\
6 \\
5\end{array}$ & $\begin{array}{l}5 \\
5 \\
5 \\
5 \\
5 \\
5 \\
5 \\
6 \\
5\end{array}$ & $\begin{array}{c}1(1) 11 \\
12 \\
12 \\
1(1) 11 \\
12 \\
1(1) 11 \\
13 \\
13 \\
1(1) 11\end{array}$ & $\begin{array}{c}1(1) 11 \\
1(1) 11 \\
12 \\
1(1) 11 \\
12 \\
12 \\
12 \\
13 \\
12\end{array}$ & $\begin{array}{c}4 \\
(1) 3(1) \\
(1) 3 \\
3(1) \\
3 \\
4 \\
\text { (not }^{\text {not }} \\
\text { (1) }^{\text {(not }}\end{array}$ & $\begin{array}{c}\text { (1)3 } \\
(1) 3 \\
(1) 3 \\
3(1) \\
3 \\
(1) 3 \\
\text { examin } \\
\text { examin } \\
\text { (1) } 3\end{array}$ & $\begin{array}{l}\text { None } \\
\text { None } \\
\text { None } \\
\text { None } \\
\text { None } \\
\text { None } \\
\text { ed) } \\
e d) \\
\text { None }\end{array}$ \\
\hline
\end{tabular}

* Including supracaudals. Number of scutes smaller than half the dimensions of normal marginals is parenthesized and inserted at suitable position.

** Number of small inframarginals, sometimes wedged in between marginals and axillaries (or inguinals) is shown in parenthesis just prior (or posterior) to the number of enlarged inframarginals.

$+\mathrm{SC}=$ supernumerary costals wedged in between costals and marginals.

$\$$ Stuffed specimen.

to $620 \mathrm{~mm}$ in carapace length, from the coast of Senegal, West Africa, the width of which is 86.4 to $97.1 \%$ of the length. Deraniyagala (1961) reports two specimens caught off India; in the 546 $\mathrm{mm}$ long female carapace the width is $98.4 \%$ of the length, while in the $680 \mathrm{~mm}$ long male carapace the width is $89.7 \%$ of the length. A few specimens of the same species accessible to me (cf. Nishimura \& HARA 1967) show the following dimensions:

$\begin{array}{llll}\begin{array}{l}\text { Locality } \\ \text { South Pacific (Yokosuka City }\end{array} & \text { Length }(L) & \text { Width }(W) & 100 \times W / L \\ \quad \begin{array}{l}\text { Museum Specimen) } \\ \begin{array}{l}\text { Shiganoshima, northwest } \\ \quad \text { Kyushu }\end{array}\end{array} & 288 \mathrm{~mm} & 278 \mathrm{~mm} & 96.5 \\ \begin{array}{l}\text { Teradomari, near Niigata on } \\ \text { the Japan Sea coast }\end{array} & 450 & 430 & 95.6 \\ \end{array}$

Number of Vertebrals and Costals. Most or $93.6 \%$ of the 78 specimens examined have five vertebral scutes (Table 1), four or $5.1 \%$ have six, and a single specimen is found to have nine vertebrals abnormally arranged (Fig. 1c, d $)^{3}$, while none is known with vertebrals less than five. Five pairs of

3) A similar abnormality in vertebral scute arrangement is shown in a grown-up specimen from West Pakistan by Minton (1962). 

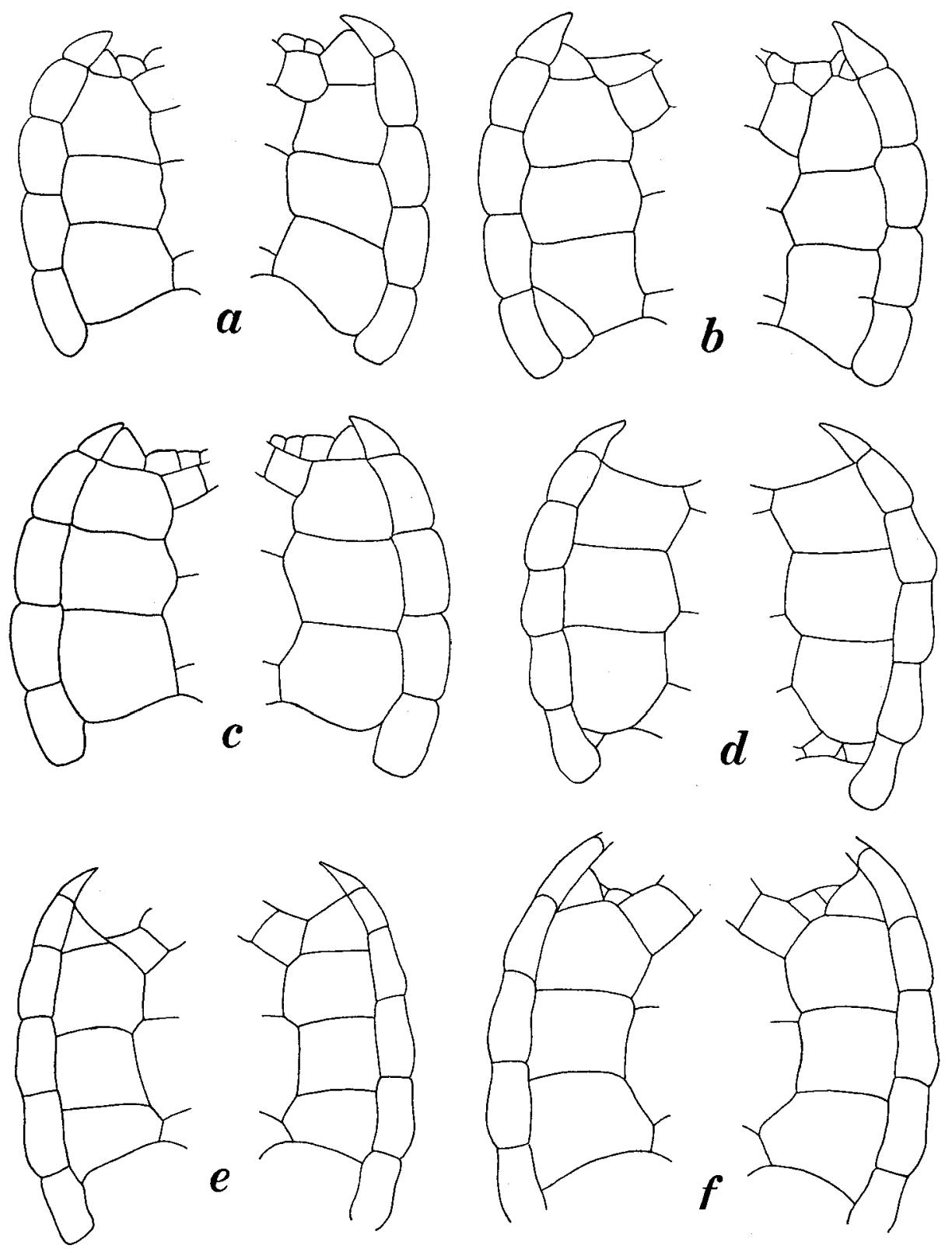

Fig. 2. Inframarginal pattern in Caretta caretta (LINNÉ) from Sirahama.

a.-Specimen no. 6628 ; b.-Specimen no. 6632 ; c.-Specimen no. 6658 ; d.-Specimen no. OB4; e.-Specimen no. OB6; $f$.-Specimen no. OB9. 
costal scutes are met with most frequently, but ten individuals or $12.8 \%$ have costals of other numbers else than five on either or both sides (Table 1; Fig. 1b,c); for convenience' sake the number of costals on the right and left sides may be treated respectively as an independent statistic element, then four costals occur in seven of the 156 cases $(4.5 \%)$, five costals in 142 cases $(91.1 \%)$, six costals in six cases $(3.8 \%)$, and seven costals in a single case $(0.6 \%)$. The situation is quite different in Lepidochelys olivacea, which is armoured with four to nine, but mostly five to seven, vertebrals and three to nine, but mostly six or seven, pairs of costals (Derantyagala 1939, 1961; Loveridge \& Williams 1957; Brongersma 1961; Nishimura \& Hara 1967; etc.) In three of the 78 specimens examined (3.8\%), one or two supernumerary costals are found inserted between costals and marginals on both sides (two specimens) or on one side (one specimen) (Fig. 1d).

Number of Marginals. The number of marginal scutes (including supracaudals) on either side in the 78 specimens is distributed as follows: 12 marginals in 89 cases $(57.0 \%), 13$ marginals in 65 cases $(41.7 \%)$ and 14 marginals in two cases $(1.3 \%)$; the average number is calculated as 12.44 . As seen clearly in Table 1, one or two marginals, most often those of the first or/and second pair, and rarely the anterior three marginals on either side are almost consistently smaller than the others in the cases of 13 or 14 marginals. This seems to suggest that 12 marginals are normal in the Japanese population of Caretta caretta. When Deraniyagala (1933, 1943, 1945, 1946) proposed two subspecies of Caretta caretta, he referred to the number of marginal scutes as one of the diagnostic characters by which he ascertained the propriety of subdivision; however, this seems quite doubtful as pointed by Brongersma (1961). In this respect, it is interesting that the Sirahama specimens show the tendency to have marginals fewer by one than those in the specimens from the Indian Ocean (Deraniyagala 1961) or the Solomon Islands (CARR 1952).

Inframarginals. In the 76 specimens examined (in two large live individuals in the aquarium it was difficult to examine the plastron), the number of inframarginal scutes on either side is distributed as follows: three inframarginals in nine cases $(5.9 \%)$, four inframarginals in 123 cases $(80.9 \%)$ and five inframarginals in 20 cases $(13.2 \%)$; the average number is 4.07 . The anteriormost scute, and occasionally also the posteriormost one, in the individuals with four or five inframarginals are generally reduced in size as compared with the remaining scutes; the degree of reduction varies individually and in many cases it is impossible to make a clear distinction between the normal (enlarged) and the reduced inframarginals (Fig. 2). In no specimen are found inframarginal pores. It had ever been believed that Caretta caretta has constantly three enlarged inframarginals on either side, while Lepidochelys olivacea has four enlarged inframarginals, and this was accepted by NAKAMURA \& UÉNo (1963), too. However, since 1952 when WiL..GoHs reported a specimen of C. caretta with four enlarged inframarginals from the coast of Norway, evidences have been accumulated against such a generalization (CARR 1952; Caldwell 1959; Brongersma 1961; etc.) And now it is clear that this cannot be applied to the Sirahama specimens and in all probability either to other populations frequenting the coasts of southern Japan. Presence or absence of inframarginal pores, on the other hand, may be still useful as a clue for discriminating Caretta from Lepidochelys.

Head Shields. Considerable variations are found in the form and arrangement of the head shields, some examples of which are shown in Fig. 3. There is a large frontoparietal, which is usually partly divided into left and right halves by longitudinal incisures originating at the anterior and posterior borders (Figs. $3 a, b, c, d$ ); occasionally it may be completely divided by a continuous incisure (Fig. $3 e$ ). Frontal is hexagonal in shape and usually much smaller than frontoparietal; sometimes a minute shield may be inserted between the frontal and frontoparietal (Fig. $3 b$ ). Of the two pairs of prefrontals, the anterior pair are usually smaller than the posterior; in many cases the left and right prefrontals are partly or wholly separated from each other by the insertion of small additional shields (Figs. $3 a, b$, $c, e, f)$. Usually four to six parietals are found; they are in most specimens much shorter than the frontoparietal in contrast with the case of Lepidochelys olivacea, in which parietals are fewer and larger.

Mandibular Scales. The shape and number of mandibular scales show a wide range of variation. Some specimens have three large scales in a horizontal row (Fig. 4b), often with the central scale of the series much smaller than others (Figs. $4 d, e, f$.) The central scale may be reduced so much that the anterior and posterior scales come into contact; in some specimens it is reduced to a small, triangular 

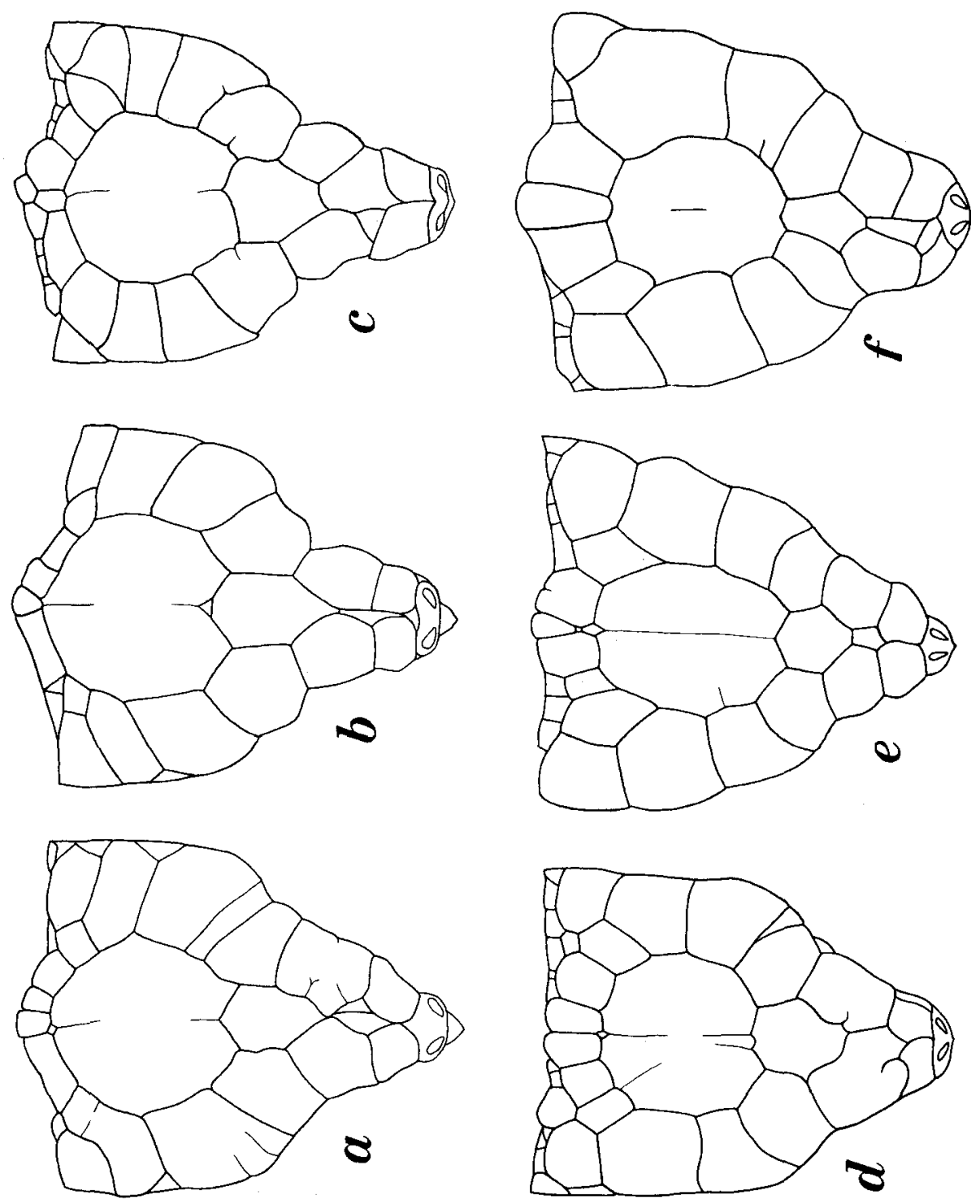

Fig. 3. Patterns of head shields in Caretta caretta (LinNe) from Sirahama. $a .-$ Specimen no. $6628 ; b$.-Specimen no. $6632 ; c$. -Specimen no. $6658 ; d$. -Specimen no. OB4; e.-Specimen no. OB6; $f$.-Specimen no. OB9. 
scale inserted between the lower parts of the other scales (Fig. 4a), and it may disappear completely as in the case shown in Fig. $4 c$. Such a pattern and variation in the arrangement of mandibular scales are quite similar to those found in the specimens from the Atlantic waters (cf. BRONGERSMA 1961).

Besides Sirahama and its vicinity, several places in southern Japan are known as the breeding grounds of the loggerhead turtles; these places are plotted on the map in Fig. 5. The turtles landing on these grounds or caught in the nearby waters were identified on actual specimens or their photographs, or on the description made in informations; and all of the identified individuals have proved belonging to Caretta caretta.
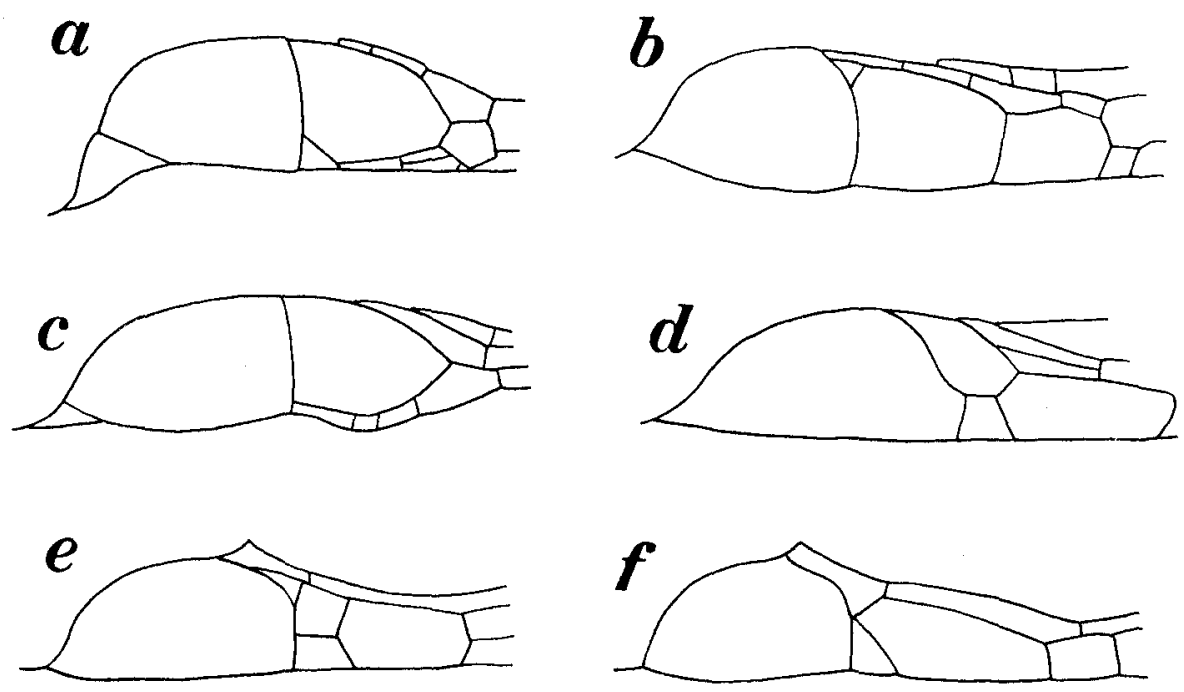

Fig. 4. Left mandibular scales in Caretla caretta (LinNÉ) from Sirahama. a.-Specimen no. 6628; b.-Specimen no. 6632; c.-Specimen no. 6658; d.-Specimen no. OB4; e.-Specimen no. OB6; $f$.-Specimen no. OB9.

In certain places, this sea turtle is fairly abundant. For instance, the number of turtles landed on Gamoda coast, Tokushima Prefecture (no. 18 in Fig. 5), in the breeding season from spring to summer, is reported as 140 in 1957, 392 in 1958, and 750 in 19594); populations breeding in the localities in southern Kyushu such as Miyazaki (no. 25 in Fig. 5), Daihô of Gotô Islands (no. 37) and Fukiage-hama, Kagoshima Prefecture (no. 30) are considered large enough to support the local commercial demand for turtle eggs as food ${ }^{5}$. However, it cannot be denied that the turtle populations as a whole are decreasing year after year in the Japanese waters. This is because of the destruction of their breeding grounds by terrible, thoughtless modification of beach on the one hand and of the uncontrolled collecting or killing of eggs and adults done quite freely in many of the breeding places on the other.

4) From a newspaper article in the Asahi Shimbun (ed. 5), Sept. 20, 1959.

5) From the article in the Dobutsugaku Zasshi, vol. 3, p. 517 (1891), YAmaGuari's (1966) paper and an information from Mr. S. KimurA of the Fisheries Institute, Kyushu University (Oct. 12, 1966). 


\section{Distribution of the Loggerhead Turtles in the Western Pacific}

From time to time loggerhead turtles are stranded on the coasts of northern Honshu. For instance, the following records are confirmed along the beach of Yamagata Prefecture; Mr. Chiуota Sugrhara of Sakata City, who kindly checked every specimen, live or preserved, found that all recorded individuals were Caretta caretta, and sent me the details of his examinations.

\begin{tabular}{|c|c|c|}
\hline Date & Locality & Carapace length \\
\hline 1909 & Miyanoura, Sakata & ca. $80 \mathrm{~cm}$ \\
\hline Before 1911 & Kamo, Tsuruoka & ca. 100 \\
\hline Before 1938 & Atsumi & 91 \\
\hline After 1940 & Yunohama, Tsuruoka & ca. 90 \\
\hline January, 1945 & Jurizuka, Sakata & 101 \\
\hline Mar. 10, 1961 & Mejika, Yusa & 85 \\
\hline June (?), 1961 & Hôki, Tobishima Isl. & 97 \\
\hline January, 1963 & Jurizuka, Sakata & 12 \\
\hline Jan. 14, 1964 & Deshimizu, Yusa & 95 \\
\hline February, 1964 & Jurizuka, Sakata & 10 \\
\hline Jul. 3, 1964 & Nezugaseki & ca. 90 \\
\hline ? & Jurizuka, Sakata & 89 \\
\hline
\end{tabular}

While he was searching for the specimens of sea turtles in that district, Mr. SugIHARa found besides Caretta caretta three specimens of the hawksbill Eretmochelys imbricata (LINNÉ), two specimens of the green turtle Chelonia mydas (LINNÉ) and three specimens of the leatherback turtle Dermochelys coriacea (Linné); it is apparent that the red-brown loggerhead is the commonest of the sea turtles caught along the coast of Yamagata Prefecture.

Caretta caretta may be observed similarly in other districts of northern Honshu, too. This sea turtle was once caught in Peter the Great Bay of the Maritime Province of the U.S.S.R. (Terentjev \& Chernov 1949). The loggerheads caught occasionally on the coasts of Hokkaido (Sh. Nozawa in Okada 1930; T. Ueno, personal communication Nov. 16, 1966) most probably belong to the same species.

On the other hand, the olive loggerhead Lepidochelys olivacea seems very rare in the Japanese waters. So far, only two specimens are confirmed, one from northwest Kyushu and the other from the coast near Niigata (Nishimura \& Hara 1967); of course, no definite record of breeding on the Japanese coasts. It seems that this turtle cannot breed in the waters surrounding Japan and a few individuals ever caught are nothing but strays from its natural habitat.

Loggerhead turtles are recorded also from Kwangtung, Fukien, Chekiang and Kiangsu on the Chinese continental coasts (FANG 1934, as Caretta caretta; Pope 1935, as C. caretta olivacea; Sowerby 1936, as C. olivacea; Hu et al. 1962, as C. caretta; etc.). According to Pope (op. cit.), they are seemingly rather rare in the Chinese waters; and the same may be true as to the neighboring waters of Hong Kong (HerkLots 


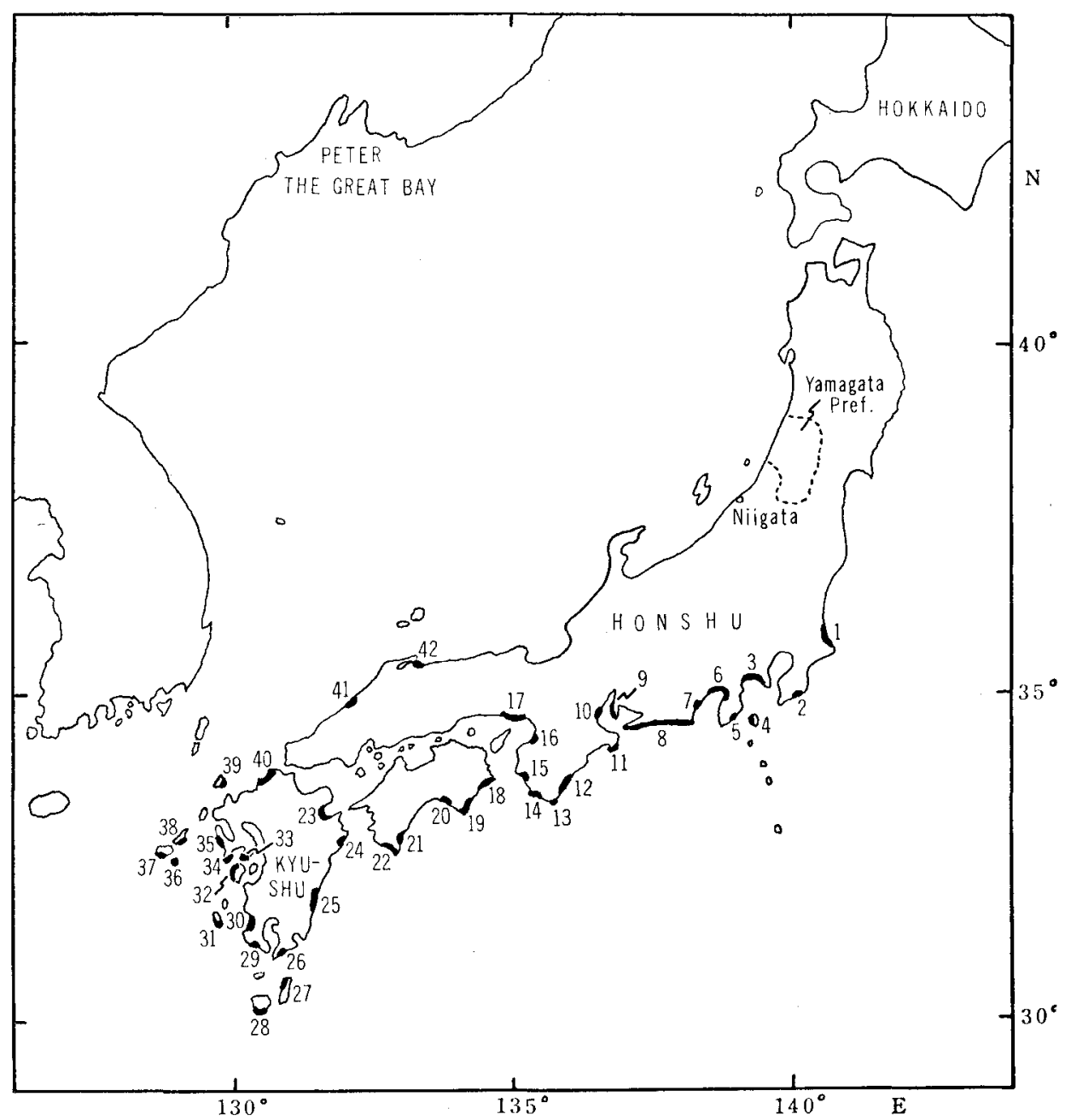

Fig. 5. Breeding places of Carelta caretta (LıNNÉ) in Japan.

1.-Kashima Nada; 2.-Kamogawa to Amatsu (cf. Ikeda 1893; KurATA 1958); 3.-Odawara to Kamakura (cf. Yoshinaga 1891; Ikeda 1893); 4.-Izu Oshima (cf. Kurata 1958); 5.-Izu Sirahama; 6.-Tagonoura; 7.-Miho; 8.-Irako to Omaezaki; 9.-Utsumi to Shin-Maiko (now abandoned); 10.-Shirako (now abandoned ?); 11.-Katada; 12.-Kumano Nada; 13.-Kushimoto; 14.-Susami, Sirahama and Minabe; 15.-Gobô; 16.-Takaishi; 17.-Maikohama to Suma; 18.-Hiwasa to Gamôda; 19.-Muroto to Sakihama; 20.-Aki; 21.-Ookihama; 22.-Oohama, Tatsukushi Sakurahama, Oogetus Matsusaki, Nishidomari Shurahama (cf. WAdA \& Kojrma 1960); 23.-Bay of Beppu; 24.-Takenoura Gôchi; 25.-Oryuzako, Miyazaki and Akae; 26.-Satamisaki Oodomari; 27.-Tanegashima Hanasatosaki; 28.-Yakushima Kurio (cf. FujIwARA 1966); 29.-Chiran coast; 30.-Fukiagehama; 31.-Koshikijima Teuchi; 32.-West coast of Amakusajima; 33.-Katsusa; 34.-Wakimisaki; 35.-Ooseto Yukinoura; 36.-Gotô Akashima; 37.-Daihô; 38.-Narao Takaitabi; 39.-Iki Tsutsugi (the data for Nagasaki Prefecture after YAMAGughr 1966); 40.-Shiganoshima, Tsuyazaki and Kôminato; 41.-Gótsu Hashi; 42.-Yumigahama (cf. Kamita 1962). 
1931). FANG's (op. cit.) statement that it is very common off the Paracel Islands in the South China Sea needs confirmation, because there is a possibility that this author deals here with Lepidochelys olizacea. TAKashima (1958) mentioned occurrences of ' $C$. caretta' in Korea, the Loochoo (Ryukyu) and Formosa, but it is left uncertain whether those turtles were all C. caretta or some olive loggerheads were included. Nothing is mentioned as to C. caretta in SHannon's (1956) report on the reptiles of Korea. Chen's (1956) description of ' $C$. olivacea' from Formosan waters seems to refer really to the red-brown loggerhead; but only Suao and Lanshui are listed as localities. WANG \& WANG (1956) and WANG (1962) list ' $C$. caretta olivacea' in the reptilian fauna of Formosa and Botel-Tobago (Kôtôsho), but it is quite uncertain whether or not it represents the true red-brown loggerhead. Orada, N. (1891, as Chelonia caouana) and OKADA, Y. (1930, as Caretta olivacea) record occurrences of the loggerhead in the Bonin Islands; though it is unknown whether it belongs to the real C. caretta or not, the latter author mentions that ' $C$. olivacea' is rare in Bonin waters, while the green turtle is very abundant there.

TAYLOR (1921, as Caretta olivacea) records occurrences of the loggerhead in Philippine waters; the single specimen he dealt with seems to be really an olive loggerhead according to his description and photographs, though it shows some morphological anomalies. In his monographic work on the turtles of Indo-China, Bourret (1941) mentioned occurrences of Eretmochelys imbricata, Chelonia mydas and Caretta olivacea (=Lepidochelys olivacea), but Caretta carelta was not included in the cheloniid turtle fauna of that area; it is mentioned plainly that $C$. caretta ( $=$ C. gigas according to his nomenclature) had not yet been found along the coast of the Peninsula of Indo-China. The red-brown loggerhead seems uncommon on the South China Sea coasts of Malaya and Sarawak, too, as Hendrickson $(1958,1966)$ and Hendrickson \& Alfred (1961) do not mention any occurrence of this species in their reports on the breeding populations of sea turtles, especially in respect to the green turtle, on those coasts. DE RoOIJ (1915) listed up the following places as the localities of 'C. caretta': Java (Batavia), Solor Island, Borneo, Celebes (Menado), Ambon, Aru Islands, New Guinea, N. \& W. Australia, Philippines, and Malay Peninsula in addition to some exo-Pacific localities. Her citations, however, cannot be taken wholly valid, since her ' $C$. caretta' seems to comprize Lepidochelys olivacea as well. According to Gibson-Hill (1950), the sea turtle fauna of the Cocos-Keeling Islands, south of Sumatra, is represented by Chelonia mydas and Eretmochelys imbricata and that of Christmas Island, south of Java, consists of only Ch. mydas; the occurrence of Caretta caretta or Lepidochelys olivacea around these offshore islands is quite unknown.

On the data cited above, though they are still insufficient and rather fragmentary, it is considered that the red-brown loggerhead is rather scarce in the tropical and subtropical areas of the western Pacific in contrast with southern Japan where it is quite common.

As to the olive loggerhead, on the other hand, there are evidences suggesting 
its frequent occurrences in the tropical-subtropical areas. TIRANT (1885, as Caouana olivacea) and Bourret (1941, as Caretta olivacea) report this sea turtle from Indo-China; according to these authors, its scutes are abundantly used in local tortoise-shell industries, though they are of a lower quality-evidently this suggests its abundant occurrences in that area. The species seems also common on the South China Sea coasts of Malay Peninsula and Borneo (Hendriakson 1958; Hendriakson \& Alfred 1961). Brongersma (1961) cited many specimens, mostly hatchlings, from Java, Flores in Lesser Sunda, Menado in Celebes, Philippines, Moluccas, Cape York in northern Australia, etc. Of the two loggerhead specimens reported by Pope (1935) from the Fukien coast, China, one (Shanghai Museum no. 2579) seems to belong to Lepidochelys olivacea, judging from the number of costal scutes (left 6, right 7). Gadow (1899) examined hatchlings from New Britain to formulate his 'theory' on the variation of the carapace scutes in loggerheads; those specimens are now considered as L. olivacea (cf. Deraniyagala 1933). Also it is to be remembered that the type specimen of $L$. olivacea was collected from the Bay of Manila (Eschscholtz 1829), and that the localities of Chelonia dussumierii DumÉrIL \& BIBron, 1835, Ch. polyaspis Bleeker, 1857 and Ch. dubia BleEker in Gray, 1864, all now placed in the synonymy of L. olivacea (Loveridge \& Williams 1957), were the China Sea (-South China Sea?), Java and Borneo, respectively. Finally, according to TAYLoR (1921), 'Caretta olivacea', presumably representing $L$. olivacea as suggested above, is not rare and is taken frequently in Manila Bay.

Meanwhile, the red-brown loggerhead becomes again very common in further southerly waters in the Southern Hemisphere. For instance, it is one of the sea turtles met with most frequently, together with the green turtle and hawksbill, in the Great Barrier Reef region of Australia (especially in the Capricorn-Bunker, i.e. the southern part of the region?) (YONGE 1930, as Thalassochelys caretta; MoORHouse 1933, as Caretta caretta; Roughley 1937, as Th. caretta; Gillett \& McNeill 1959, as C. cartta; etc.) Judging from the descriptions and photographs, there is no doubt in concluding that the loggerhead common in the Great Barrier Reef region are the true Caretta caretta. Breeding is known from further southern localities along the eastern coast of Australia: Deraniyagala (1939) examined a hatchling of the redbrown loggerhead from Bunderberg in southern Queensland $\left(25^{\circ} \mathrm{S}\right)$. The occurrences of the same species off Western Australian coast are noted by GLAUERT (1928) and Campbell (1947); it is possible that there are its breeding places on the same coast, as BABcock (1930) and Brongersma (1961) report hatchlings from Shark Bay. For the records in South Australia, the work of WAITE (1929) is to be referred to. Further, according to ScotT \& Mollison (1956, as C. caretta gigas), the red-brown loggerheads are caught not infrequently in Tasmanian waters, too. On the other hand, no information of frequent occurrences of the olive loggerhead in Australia is known to the present author, except for its northernmost districts.

From the distributional features of the red-brown loggerhead mentioned so far, 
it may be concluded that this turtle has two centers of abundant occurrences in the western Pacific, one in southern Japan and the other in Australian waters, but it is rather scarce in the tropical-subtropical region between those two areas. Thus, this sea turtle is to be called rather a warm-temperate species, but not a tropical-subtropical one as was previously believed generally. The few specimens captured in the tropical-subtropical waters may be stray individuals from the warm-temperate habitat. A similar pattern of distribution appears to be observed in the Atlantic populations of this species, too (cf. Babcogk 1938; Deraniyagala 1943; Carr 1952; Caldwell, Carr \& Hellier 1956; Caldwell, Carr et al. 1959; etc.) In expressing such a pattern of geographical distribution, the term 'antitropical' suggested by HubBs (1952) may be borrowed. As regards the tropical part of the Indian Ocean, Deraniyagala (1933, as C. gigas) states that the species is not uncommon in the Gulf of Mannar, Ceylon; strange enough, however, no definite information is made about its breeding in the Ceylonese waters, though both eggs and young of its relative olivacea are very common there. Are the bulk of the red-brown loggerheads captured in Ceylon the stray individuals derived from the southern temperate zone in the same way as this author $(1960 \mathrm{a}, 1960 \mathrm{~b}, 1961,1965)$ suggested for some pelagic animals found in the Ceylon area?

The olive loggerhead, on the other hand, may be said a typical tropical-subtropical species like the remaining chelonine turtles. It is found commonly in all the equatorial waters in the eastern Pacific, the Indian, and the eastern and western Atlantic (Deraniyagala 1939, 1943; Carr 1952, 1957; Loveridge \& Williams 1957; Villiers 1958; Brongersma 1961; Pritchard 1964; etc.) in addition to the western Pacific. The previous concept that the distribution of Caretta caretta covers the entire tropical and subtropical seas and often extends to the temperate waters is then considered to be originated erroneously by the confusion of the two species mentioned so far belonging to the same tribe, Carettini.

\section{Summary}

1. Detailed studies on the external morphology such as carapace dimensions and scute and scale arrangements were made on the loggerhead population breeding on the coast of Sirahama, southern Japan. The results indicate that the population consists of a single species: Caretta caretta (LinNé). Examination of the accessible specimens from other breeding places in southern Japan also revealed that they all belonged to the same species.

2. It seems very likely that Lepidochelys olivacea (Eschscholtz), another carettine species much confused with $C$. caretta in Japan so far, does not breed in the Japanese waters. Only two records have hitherto been confirmed as to the occurrence of L. olivacea in Japan.

3. The breeding places of $C$. caretta in the Japanese waters are shown on a map. The population of this sea turtle in Japan is estimated to be of a fairly large size. 
4. Records of occurrences of $C$. carelta and L. olivacea in the western Pacific are reviewed. It is concluded that the former is abundant in the warm-temperate regions in both hemispheres but apparently very scarce in the tropical-subtropical region between, while the latter is common in the tropical-subtropical waters and fades toward the temperate regions. The distribution pattern of $C$. caretta may be considered as an example of the 'antitropical' distribution.

\section{REFERENGES}

BABCOCK, H.L. 1930. Variations in the number of costal shields in Caretta. Amer. Naturalist, vol. 64, pp. 95-96.

1938. Field guide to New England turtles. New England Mus. Nat. Hist., Nat. Hist. Guide, no. 2, 56 pp.

Bourret, R. 1941. Les tortues de l'Indochine. Inst. Océanogr. l'Indochine, Note 38, 235 pp., pls. I-XLVII et A-F (col.)

Brongersma, L.D. 1961. Notes upon some sea turtles. Zool. Verhand., Leiden, no. 51, 46 pp., pl. I. Cadenat, J. 1949. Notes sur les tortues marines des côtes du Sénégal. Bull. Inst. Franç. Afr. Noire, vol. 11, pp. 16-35.

Galdweld, D.K. 1959. The loggerhead turtles of Cape Romain, South Florida. Bull. Fla. State Mus., Biol. Sci., vol. 4, pp. 319-348.

- Carr, A. \& Hellier, Th. R., JR. 1956. Natural history notes on the Atlantic loggerhead turtle, Caretta caretta caretta. Quart. J. Fla. Acad. Sci., vol. 18, pp. 292-302.

- CArr, A. et al. 1959. The Atlantic loggerhead sea turtle, Caretta caretta caretta (L.), in America. Bull. Fla. State Mus., Biol Sci., vol, 4, pp. 293-348.

Campbels, J.B. (ed.) 1947. Handbook of Western Australia, A.N.Z,A,A.S., Perth,

CARR, A. 1952. Handbook of turtles. New York.

- 1957. Notes on the zoogeography of the Atlantic sea turtles of the genus Lepidochelys. Rev. Biol. Trop., Costa Rica, vol. 5, no. 1, pp. 45-61.

Chen, J.T.F. 1956. A synopsis of the vertebrates of Taiwan. Taipei. (In Chinese).

Deraniyagala, P.E.P. 1933. The loggerhead turtles (Carettidae) of Ceylon. Ceylon J. Sci., sect. B, Zool. \& Geol., vol. 18, pt. 1, pp. 61-72, pl. V.

1939. The tetrapod reptiles of Ceylon. Vol. 1-Testudinates and crocodilians. Colombo.

1943. Subspecies formation in loggerhead turtles (Carettidae). Spolia Zeylanica, vol. 23, pt. 2, pp. 79-92.

1945. Some subspecific characters of the loggerhead Caretta caretta gigas. Spolia Zeylanica, vol. 24, pt. 2, pp. 95-98.

_ 1946. Marginal scutes in races of the brown-red loggerhead Caretta caretta Linné. Spolia Zeylanica, vol. 24, pt. 3, pp. 195-196, pl. XXV.

- 1960a. Some southern temperate zone snakes, birds and whales that enter the Ceylon area. Spolia Zeylanica, vol. 29, pt. 1, pp. 79-85.

1960b. Antarctic hydrographic fluctuation as suggested by animals that reach Ceylon. Proc. Roy. Soc. (B), vol. 152, p. 634.

-1961a. Some little known characters of the two subspecies of Lepidochelys olivacea (Eschscholtz). Spolia Zeylanica, vol. 29, pt. 2, pp. 196-201, pls. I-II.

1961b. Some southern temperate zone fishes, a bird and whales that enter the Ceylon area. Spolia Zeylanica, vol. 29, pt. 2, pp. 232-237, pl. I.

1965. Comparison of Mesoplodon hotaula Deraniyagala with Ziphius cavirostris indicus (van

Beneden). Spolia Zeylanica, vol. 30, pt. 2, pp. 251-260, pls I-III.

Eschscholtz, F. 1829. Zoologischer Atlas enthaltend Abbildungen und Beschreibungen neuer Thierarten während des Flottcapitains von Kotzebue zweiter Reise um die Welt, auf der RussischKaiserlichen Kriegsschlup Predpiaetrië, in den Jahren 1823-1826 beobachtet. Heft I, pp. 1-17, pls. I-V. Berlin. 
FANG, P.W. 1934. Notes on some Chelonians of China. Sinensia, Nanking, vol. 4, pp. 145-199.

Fujiwara, M. 1966. The early development of the marine turtle with special reference to the formation of the germ layers in Amniota. Bull. Tokyo Gakugei Univ., vol. 18, ser. IV, no. 1, pp. 4760. (In Japanese).

Gadow, H. 1899. Orthogenetic variation in the shells of Chelonia. Willey's Zool. Results, pt. III, pp. 207-222, 2 pls.

Gibson-Hill, C.A. 1950. A note on the reptiles occurring on the Cocos-Keeling Islands Bull. Raffles Mus., Singapore, no. 22, pp. 206-211.

Gillett, K. \& MaNeill, F. 1959. The Great Barrier Reef and adjacent isles. Sydney.

Glavert, L. 1928. The vertebrate fauna of Western Australia. J. Roy. Soc. W. Austr., vol. 14, pp. 61-77.

Hendriakson, J.R. 1958. The green sea turtle, Chelonia mydas (Linn.) in Malaya and Sarawak. Proc. Zool. Soc. London, vol. 130, pp. 455-535, 10 pls.

1966. Observations on the fauna of Pulau Tioman and Pulau Tulai 5. The reptiles. Bull. Nat. Mus. Singapore, no. 34, pp. 53-71.

\& Alfred, E.R. 1961. Nesting populations of sea turtles on the east coast of Malaya. Bull. Raffles Mus., Singapore, no. 26, pp. 190-196.

G.A.C.H. [Herklots, G.A.C.] 1931. Eretmochelys imbricata (Pennant). Hong Kong Naturalist, vol. 2, pp. $82-83,2$ pls.

Hirasaka, K. 1943. [On sea turtles]. J. Soc. Trop. Agr., Taihoku, vol. 15, pp. 94-98. (In Japanese). Hotra, H. 1960. [Vertebrates]. In Tanita, S.: Fisheries zoology, pp. 204-243. Tokyo. (In Japanese). Hu SHU-QIN et al. 1962. [Illustrated encyclopedia of the animals of China: Reptilia]. Peking. (In Chinese).

Husbs, G.L. 1952. Antitropical distribution of fishes and other organisms. Seventh Pacific Sci. Congr., vo. 3, 6 pp.

IkedA, S. 1893. [Sea turtles]. Dobutsugaku Zasshi, vol. 5, p. 113. (In Japanese).

Kamita, T. 1962. Visits by unusual aquatic animals to the sea coasts of San-in District, Japan Sea. San-in Bunka Kenkyu Kiyô, no. 2, pp. 1-35. (In Japanese).

Kurata, Y. 1958. [Notes on sea turtles]. Ushio, Tokyo, no. 19, pp. 9-10. (In Japanese).

Loveridge, A. \& Williams, E.E. 1957. Revision of the African tortoises and turtles of the suborder Cryptodira. Bull. Mus. Comp. Zool., vol. 115, pp. 163-557, 18 pls.

Minton, S.A., Jr. 1962. An annotated key to the amphibians and reptiles of Sind and Las Bela, West Pakistan. Amer. Mus. Novit., no. 2081, 60 pp.

Moorhouse, F. W. 1933. Notes on the green turtle (Chelonia mydas). Repts. Great Barrier Reef Comm., Brisbane, vol. 4, pp. 1-22, 3 pls.

Nakamura, K. 1957. [Reptilia]. In Encyclopaedia zoologica illustrated in colurs I, pp. $204-243$. (In Japanese).

\& UÉNo, SH. 1963. Japanese reptiles and amphibians in colour. Osaka. (In Japanese).

Nishimura, S. \& Hara, K. 1967. The status of the sea turtles of the genera Caretta and Lepidochelys in Japanese waters (Testudinata: Cheloniidae). Acta Herpet. Japon., vol. 2, pp. 31-35. (In Japanese).

Oogami, U. 1900. [Tortoises and turtles of Province Harima]. Dobutsugaku Zasshi, vol. 12, pp. 263-264. (In Japanese).

Okada, T. (ed.) 1891. [Catalogue of animals of Japan: Vertebrata]. Tokyo. (In Japanese).

Okada, Y. 1927. [Reptilia]. In Illustrated encyclopedia of the fauna of Japan, pp. 191-234. Tokyo. (In Japanese).

1930. Notes on the herpetology of the Chichijima, one of the Bonin Islands. Bull.

Biogeogr. Soc. Japan, vol. 1, pp. 187-194, 1 pl. (In Japanese).

1938. A catalogue of vertebrates of Japan. Tokyo.

1947. [Reptilia]. In Illustrated encyclopedia of the fauna of Japan (rev. ed), pp. 223-271.

Tokyo. (In Japanese).

Pritchard, P.C.H. 1966. Sea turtles of Shell Beach, British Guiana. Copeia, 1966, pp. 123-125. 
DE Roorj, N. 1915. The reptiles of the Indo-Australian Archipelago I. Lacertilia, Chelonia, Emydosauria. Leiden.

Roughley, T.C. 1937. Wonders of the Great Barrier Reef. Sydney.

Scott, E.O.G. \& Mollison, B.C. 1956. The Indo-Pacific redbrown loggerhead turtle, Caretta caretta gigas Deraniyagala, and the leathery turtle, Dermochelys coriacea (Linné) in Tasmanian waters. Pap. \& Proc. Roy. Soc. Tasmania, vol. 90, pp. 59-63, 1 pl.

Shannon, F.A. 1956. The reptiles and amphibians of Korea. Herpetologica, vol. 12, pp. $22-49$.

Sowerby, G. 1936. China's natural history: a guide of the Shanghai Museum (R.A.S.) Roy. Asiat. Soc., N. China Branch, Shanghai, 108 pp.

SteJNEGER, L. 1907. Herpetology of Japan and adjacent territory. Bull. U.S. Nat. Mus., vol. 58, $\mathrm{xx}+577 \mathrm{pp}$.

Takashima, H. 1932. A list of turtles of the Japanese Empire. Trans. Nat. Hist. Soc. Formosa, vol. 22, pp. 152-163. (In Japanese).

1958. A synopsis of the reptiles of Japan. Misc. Rep. Yamashina's Inst. Ornith. \& Zool., no. 12, pp. 486-493. (In Japanese).

TAylor, E.H. 1921. Amphibians and turtles of the Philippine Islands. Bureau of Science Publ, Manila, no. 15,193 pp.

Terentjev, P.V. \& Chernov, A.S. 1949. [Key to the reptiles and amphibians]. Moscow. (In Russian).

TiRant, G. 1885. Notes sur les reptiles et les batraciens de la Cochinchine et du Cambodge: Les tortues. Excurs. et Reconn., Saigon, vol. 19, pp. 148-168.

Utinom, H. 1943. [Sea turtles; their breeding, habits and growth]. Kaiyo no Kagaku, Tokyo, vol. 3, pp. 526-532. (In Japanese).

Viliners, A. 1958. Tortues et crocodiles de l'Afrique Noire Française. Inst. Franç. d'Afr. Noire, Initiation Afr., no. XV, 354 pp.

Wada, H. \& KoJIma, K. 1960. [Animals in the vicinity of Promontory Ashizuri]. Ashizuri Kokuritsu Kôen Kôhochi Kihon Chôsho, Kochi, pp. 70-118. (In Japanese).

WaIte, E.R. 1929. The reptiles and amphibians of South Australia. Adelaide.

Wang, Ghin-Shiang 1962. The reptiles of Botel-Tobago. Q. J. Taiwan Mus., vol. 15, nos. 3/4, pp. 141-191.

pp. $1-86$.

Wermuth, H. \& Mertens, R. 1961. Schildkröten-Krokodile-Bruckenechsen. Jena.

WillgoHs, J.F. 1952. Common loggerhead Caretta caretta (Linné) stranded in western Norway, with some remarks on its specific diagnosis. Årbok Univ. Bergen, Naturvit. Rekke, nr. 17, 8 pp.

Yamaguchi, T. 1966. Reptiles from Nagasaki Prefecture. Bull. Fac. Liberal Arts, Nagasaki Univ., Nat. Sci., vol, 6, pp. 19-36, 5 pls. (In Japanese).

Yonge, C.M. 1930. A year on the Great Barrier Reef; the study of corals \& of the greatest of their creations. London \& New York.

Yoshinaga, T. 1891. [New localities for sea turtles]. Dobutsugaku Zasshi, vol. 3, p. 466. (In Japanese).

Note Added in Proof. After I submitted the manuscript for printing, I received from Dr. Charles McCann of the New Zealand Oceanographic Institute two very interesting papers on marine reptiles in the New Zealand waters ("Key to the marine turtles and snakes occurring in New Zealand." Tuatara, vol. 14, pp. 73-81, 1966; "The marine turtles and snakes occurring in New Zealand." Rec. Dominion Mus., vol. 5, pp. 201-215, 1966). From the descriptions, photographs and illustrations given in these papers, it is clear that both the red-brown and the olive loggerhead occur in the New Zealand waters, though they are lumped together under the name 'Caretta caretta'. The occurrences of young specimens on Ninety-mile Beach, one of which is shown on Plate III of the paper in Records of the Dominion Museum and is almost certainly a young of the true $C$. caretta, suggest that there are its breeding places in nearby areas. It is much expected that further studies will be made to reveal the relative abundance of each of the species and whether or not these turtles, especially $C$. caretta, are really nesting in the New Zealand waters. 